\title{
The Protestant Ethic and the Spirit of Capitalism: Entrepreneurship of the Norwegian Puritan Leader Hans Nielsen Hauge
}

\author{
Ola Honningdal Grytten ${ }^{1}$ \\ ${ }^{1}$ Department of Economics, Norwegian School of Economics, Bergen, Norway \\ Correspondence: Ola Honningdal Grytten, Department of Economics, Norwegian School of Economics, \\ Helleveien 30, N-5045 Bergen, Norway. Tel: 47-55-959-345. E-mail: Ola.Grytten@nhh.no
}

Received: December 17, 2012 Accepted: January 11, 2013 Online Published: February 18, 2013

doi:10.5539/res.v5n1p31 URL: http://dx.doi.org/10.5539/res.v5n1p31

\begin{abstract}
The present paper deals with Max Webers hypothesis on the linkage between protestant ethics and the development of capitalism and entreprenaurship. It does so by study industrial entrepreneurship the great Norwegian puritan pioneer and leader Hans Nielsen Hauge (1771-1824) was engaged in. Specificially, the paper seeks to map his involvement in starting or restarting businesses and to quantify the volumes of financial activities he was engaged in. The paper concludes that the industrial activities initiated by Hauge was of a substantial size to the Norwegian economy in the 19th century.
\end{abstract}

Keywords: business history, entrepreneurship, protestant ethics, religion, economic growth

\section{Introduction}

"The Puritan wanted to work in calling; we are forced to do so. For when asceticism was carried out of monastic cells into everyday life, and began to dominate worldly morality, it did its part in building the tremendous cosmos of the modern economic order. This order is now bound to the technical and economic conditions of machine production which today determine the lives of all the individuals who are born into this mechanism, not only those directly concerned with economic acquisition, with irresistible force. Perhaps it will so determine them until the last ton of fossilized coal is burnt." (Weber 1930).

Several scholars, and perhaps the most prominent of them, Max Weber, have tried to explain why Christian puritans tended to be pioneers within industrial development and economic growth. In order to explain this phenomenon one has focused on different puritan movements' emphasize on the concept of God's calling to individuals, who are responsibile for echoing this calling. It has been argued that the response has been materialised by modesty, discipline, asceticism, strong working moral, capital accumulation, reinvestment and entrepreneurship. The latter has in its turn been considered crucial for economic growth and development (Tawney, 1926; Engerman, 2000; Schumpeter, 1939).

A significant entrepreneurial environment during the Norwegian $19^{\text {th }}$ century take off was made up by puritans. This was descending from the lay preacher Hans Nielsen Hauge (1771-1824). He was a true entrepreneur within many fields, e.g. industrialization, trade, shipping services, financing, popular education, and political, social and religious reforms (Magnus 1978).

\subsection{Problem Defined}

The present paper sets out to investigate into two different aspects connected to Hauge:

1. Map Hauge's industrial entrepreneurship.

2. Quantify the size of Hauge's engagements as investor and banker.

Thus, we will here look into what kinds of businesses Hauge was involved in. We will try to find out what kind of portfolio he invested in and give estimates of the size of his engagements. The paper basically examines his role as investor and banker and quantifies the size of this engagement.

\subsection{Sources and Data}

Quantification is made possible by systemizing different sources, which contain information on Hauge's business transactions. In this paper time consuming efforts have been laid down in organising the sources in a 
way that makes it possible to aggregate the volumes of financial transactions he was involved in. The first steps were made by Vegard Tafjord Rødal and Andreas Kiplesund, who systemized parts of the available data on Hauge's financial activities (Rødal, 2009). In their dataset we find posts of financial transactions he played an active or mediatory role in. On the debit side they report investments, posted as real capital and loans and on the credit side financial posts, reported as credits or equity.

The two most important primary sources are business letters and financial accounts written by Hauge himself. The letters were collected and published by Ingolf Kornelius Kvamen (Kvamen, 1971-1976). They contain important information on investments, financial sources, income, costs, profits and terms of condition for transactions. In addition important information on Hauge's business activities were collected by Dagfinn Breistein and presented in a biography under the title Hans Nielsen Hauge: Merchant in Bergen (Breistein, 1955). This material was used in a main trial against Hauge, where his economic activities were carefully mapped, without finding any illegal action.

Given they originality and their critical assessments, these sources seem solid both considering their validity and reliability. However, there are some lacunas in the datasets as not all of Hauge's activities were registered. The volume of his engagement was, hence, larger than the estimates offered here suggest. We are able to examine both transactions where he was personally and directly involved as an active player player, and transactions, where he played a role as mediator.

A challenge with the data is to transfer the sums to relevant present time figures. Hauge was basically active as a businessman in the years spanning from 1799 until 1820, with emphasise on the period 1801-1804 (1806). Large parts of this period can be characterized by domestic monetary chaos with strong price fluctuations and substantial depreciation of the Danish-Norwegia currency (Eitrheim, 2005).

A resent research project launched by the central bank has provided datasets of both prices and exchange rates for the period in question. The series are well documented and must be considered valid and reliable for our purpose (Klovland, 2004; Grytten, 2004a). They also make it possible to relate Hauge's portfolios to the size of the Norwegian investment volumes and normal wage levels at the time (Grytten, 2004b; Grytten, 2007).

\section{The Economic Ethics of Protestantism}

Several scholars have studies the relationship between religious belief and economic development. Most of these seem to conclude that there is a positive relationship between protestant ethics and historical entrepreneurship and economic growth. However, they do not seem to agree why.

\subsection{Weber's Thesis}

The Ethic of Protestantism and the Spirit of Capitalism by Max Weber (1905) originated as an anthology of essays on possible relations between Christian puritanism and the growth of modern capitalism. His point of departure is what he describes as a fact: protestant countries were the first to become rich, and puritan groups were in the forefront of capital accumulation, investment, industrialization and economic and social progress.

Weber describes how "the spirit of capitalism" developed from protestant ethics emphasizing individual discipline, responsibilities, asceticism, and duties. He highlights the predestination doctrine according to the Swiss reformist Jean Calvin. The doctrine claims that God saves those he has chosen beforehand. Thus, one has no guarantee of salvation, but has to believe and proove that one is predestined for salvation. Work became an important tool in order to conquer doubt. Secular success and a decent moral life were taken as indications of God's grace. The faithful worked hard and rational without consuming more than necessary. Modesty was considered a fruit of Christian life. Profits were reinvested. Thus, Calvinistic mentality led to rapid industrialization and economic growth.

However, the predestination doctrine is not representative for mainstream puritan believe. Thus, Weber also generalizes on the basis of a broader point of departure, as he includes Martin Luther's teaching on God's calling, aspects from pietism, methodism and baptism. In doing so he stresses the puritan movements' emphasise on a very strong individual responsibility within their theology and way of life.

\subsection{Alternative Views}

Later, several scholars extended Weber's analysis, among them, Tawney (1926) and Engerman (2000). They consider the typical way of reasoning within the capitalist system as rational and strongly influenced by the concept of divine calling. Puritan moral promotes saving by hard work and modest spending on the individual level. Thus, capital accumulation, investment and reinvestment naturally follow the puritan way of life. This explains why protestant environments were among the first to take huge economic steps. However, Tawney 
disagreed with Weber on his thesis that Protestant ethic created the capitalist spirit since capitalism exicted in Catholic Italy before Protestantism was established. He also found the direction of causality difficult and suggested that Protestantism could as well be a fruit of capitslism as the opposite.

Grossman (2006) and Cantoni (2009) argue that population shifts were decisive for the development rather than religious affiliation. Population preassure may have motivated new ways of organising the society, new theology, new technology and, thus, economic growth. Robertson (1950) has argued that capitalism, contrary to Weber's claim, did not start to flourish in the UK, but in $14^{\text {th }}$ century catholic Italy.

In studies covering a limited part of Europe Korotayev (2006) and Becker and Wossman (Becker \& Wossman, 2009) argue that literacy more than religious affiliation can explain historical differences within these countries. However, they also stress that protestant countries became literate before catholic and orthordox countries.

In his empirical work on religious affiliation and economic growth in Western Europe since 1500, Young (2009) concludes that there is a clear correlation between Protestantism and growth until the 1950s. He argues that this was very much due to dynamic versus static ethics and mentality. Grier (1997) confirms a clear correlation between Protestantism and economic development in his quantitative study of 63 former colonies.

Resent studies have confirmed that nonconformist puritans, not bound by traditional doctrines, customs or practises, were essential as entrepreneurs and in the making of the modern economic system. Their tracks were followed by economic growth, wealth and welfare. Iannaconne (1998) argues that religious belief is often formed through rational processes and that the link between nonconformist movements and economic entrepreneurship and growth is statistical significant. This is in line with the massive British study conducted by Jeremy (1998).

A compelling and insightful work on the link between religious belief and economy is the paper by McCleary and Barro (2006). It examines statistical links between protestant ethics and growth in addition to the motivation for entrepreneurship. They conclude there is a significant relationship and find clear motivational forces in nonconfomist movements.

\subsection{Norwegian Views}

McCleary and Barro's study serves as an influential motivator for a recent Norwegian study on the Hauge movement and how it significantly influenced the 19th century transformation of the economy. In this study by Dalgaard and Supphellen (2011), Hauge and his followers' motivation and influence on the Norwegian society and economy are interpreted in light of entrepreneurial theories. This is in line with views held by writers on $19^{\text {th }}$ century Norwegian economic history.

It was first confirmed in a study from 1947 by Jonassen (1947). He showed that the industrial development in Norway did not start until the Puritan movement, primarily represented by Hauge and his followers, gained foothold in the country. Later, Sejersted (1993) argued that Haugians made up one of the most important small-scale capitalist community at the time. This view is shared in general literature on Norwegian $19^{\text {th }}$ century economic history (Hodne \& Grytten, 2000).

Vea (2009) somewhat challenges this approach in his analysis of mentality and its influence on economic development along the coastline in Western and Northern Norway. He argues that the Haugian business community chiefly was consentrated in the ereas of herring fisheries. These fisherries required a dynamic business community since it is more mobile and and unpredictable than cod fisheries. Thus, one had to rely on efficient and mobile capital, work force and business communities. This environment suited the puritan way of thinking and to some extent existed before the Hauge movement gained ground. Thus, the entrepreneurship must be seen in light of this favourable framework. Against Vea's view, it should be held that the Norwegian clipfish industry (salted and dried cod) was dominated by Haugians.

\section{Hans Nielsen Hauge}

During the 19th century Norway for the first time saw consistent long-run economic growth, despite fluctuating business cycles. At the core of the development we find some very important entrepreneurs, like the Anker family, Count Wedel Jarlsberg and Jacob All. Another important pioneer, and probably the most underestimated of them, was Hauge. His entrepreneurial activities took place during the politically and economically turbulent early 1800 s, chiefly when Norway still was under Danish rule (Lunden, 1980).

It should also be noted that the last years of the eigteenth century and the first of the nineteenth saw a substantial boom in the Norwegian economy, profiting from the European wars connected to Napoleon's European aspirations. These years gave favourable conditions to many entrepreneurs. On the other side these years were 
also quite turbulent with strong contractions in agricultural output and business, e.g. in 1802 and 1804 (Kristiansen, 1925). Hauge ran huge deficits on some of his projects in these years and needed financial assistanse from his brother in law and Johan Nikolai Loose other friends in order to continue several of his projects.

Lack of land for extended produstion of crops also made the labor force underemployed. Thus, in the countryside, labor supply was higher than labor demand (Hovland, 1978). This is also were Hauge created most jobs and got most followers.

\subsection{Background}

Hauge had a modest background as the son of a peasant from Tune, southeast in the country. Despite his modest background he ended up as a considrable entrepreneur, merchant, banker, investor, speculator, ship-owner, industrial pioneer, editor, writer, publisher, laypreacher, leader of a popular opposition and movement, as well as social, political and religious reformist. His significance for the foundation of modern Norway can hardly be exaggerated (Shaw, 1955). We hardly find any stronger Norwegian 19th century entrepreneurial network than that we find in the movemet after him.

The ideas promoted by Hauge were core values for the establishment of what we call modern Norway. His followers were active in the political, cultural, religious, and industrial life. They were pioneers within democracy building, rule of law, due process of law, liberalism, welfare, popular enlightment, entrepreneurship and social reforms. They were against centralisation of power, public spending, privileges, monopolies and political and religious systems forced on people (Kullerud, 1996; Sjursen, 1997).

\subsection{Motivation}

Central to Hauge's motivation was a deep spiritual experience when he was 25 . This was leading up to conversion from traditionalism to a more committed nonconformist life in service for God and fellowmen. He soon started as lay preacher and saw it as a divine calling to meet spiritual and physical needs. This places him in evangelical waves at the time. In theology he was firstly inspired by German pietism and secondly by British puritanism. In social, political and economic entrepreneurship he was perhaps firstly inspired by the British puritans and secondly by the German pietists as he found their practises in the German Hernhut society in Norway's biggest city at the time, Bergen. We find similar views on the spiritual responsibility of peoples material wellbeing attached to the father of the methodist movement, John Wesley (1703-1791), and the founders of The Salvation Army, William (1829-1912) and Catherine (1829-1890) Booth (Hattersley, 1999, pp. 13-30).

Like his British spiritual relatives Hauge's main goal hardly was personal success or wealth. In fact he lived a very modest life. He also preached against wealth used for personal consumption. A core value in his ethics was decent and efficient management of resources provided by God. He saw job creation as part of his responsibility towards God and his followers. In his basic writings on doctrines he emphasised the importance of economic activity for the betterment of society as God's will:

"The primary Duty is to spread Knowledge of the Word of God. However, (...) the Lord commisioned our first Parents to cultivate the Land (...) the Bretherens should, according to God's will, produce necessary Clothing and Food (...) in order to enlight them with the Love of Christ (...) To show Faithfulness in this earthly Ministry, is the Calling and Duty of Christian Citizenship (...) This is my basic doctrine. (Hauge, 1800).

Hauge viewed the faithful as God's "Housekeepers" on earth. Thus, there was a huge responsibility in not spoiling spiritual and material gifts:

"If your have been trusted some Pounds by God in the Spiritual or the Physical, be faithful Housekeepers over them, and do not magnify Yourself, but remember they are God's Property borrowed by You." (Hauge, 1796).

Thus, his believe played an important role in his entrepreneurship (Magnus 1996; Ravnåsen, 2011, pp. 103-121). Profit should be reinvested to benefit progress and the needy (Norborg, 1966, pp. 43-46). He argued that persistent gifts to the poor could destroy incentive structures and deploy them of development opportunities. The best form of aid was to enable people to provide for their families. The society would better optimize its welfare by assisting people in order to manage on their own. Hauge considered work and business as two sides of spiritual life, as long as profits were reinvested. His views were disputed by the elite of the time, and his activities were openly debated. Hauge explained himself in newspapers and magazines:

"Those who will not work should rather not eat. (...) I will, however, build Factories, be involved in Trade, work in help of Crafts, and when Time and Energy allows, preferably cultivate the Land." (Hauge, 1802). 
His business ethics mirrored the ethics of puritans abroad. They stressed the employees' obligation to work hard and the employer's responsibilities towards his employees, their families and the community (Shaw, 1955). Everybody should live and work according to his or her Christian consciousness. Hauge argued that:

"(...) Thus, naturally the Body demands its basic Needs, thereafter one must work by ones own Strength as much as one is able to." (Hauge, 1804).

He also stressed God's provision and the employer's responsibilities in a radical way:

"(God) provides us with His Blessings hidden by our Labour, Efforts and the Gifts of Nature (...) The Employees are never Subjects, but Subordinates, (...) if the Employer does not provide his Subordinates fair Salaries, Food and Clothing in due Time the Employer is a Thief." (Hauge, 1804).

In a recent study McCullough and Willoughby (2009, pp. 65-91) conclude that strong religious belief influences self-control, self-regulation and motivation, resulting in substantial work commitment, self efficacy, persistence and sense of meaningful work. Eirik N Helgøy (2010) argues that Hauge's ethics and motivation along these lines are still going strong in parts of present Norwegian business life.

\subsection{Imprisoned}

Despite Hauge started from scratch, he successfully managed to build an economic and religious empire in short time. He was arrested ten times between 1797 and 1804, and was thereafter imprisoned without verdict for seven years from October 1804 onwards. Admittedly, he was released for a seven-month period in 1809 in order to help the authorities with the establishment of salt distillation plants during the British blockade after the Danish support to Napoleon's war against the United Kingdom.

Hauge was convicted to two years of slavery in 1813. 300 witnesses were interviewed in hope of pleading him guilty of economic and financial fraud. His financial transactions and dispositions were carefully investigated. However, the prosecution authorities could not find anything illegal in this field. Finally, he was sentenced for illegal religious activities. He had been preaching without the consent of local vicars, which was illegal in Norway at that time. During 1814 the sentence was reduced to a fee of 1000 riksdaler, which basically was paid by people in his business network (Bull, 1908; Hauge, 1963; Elseth 1998; Supphellen, 2012).

Hauge was both a theological and political threat to the establishment at his time. He was popular in huge parts of the general public and had faithful followers almost everywhere. They were promoting individual, political, economic liberty. Thus, the political motivation for his arrest should not be underestimated (Koht, 1934; Christoffersen, 1996; Furre, 1997). At least three of Hauge's followers were elected members of the Norwegian popular assembly, which played an active role the demolition of the Danish-Norwegian union.

\subsection{Part of International Wave}

Hauge's influence on the Norwegian society has been considered imperative in many ways. Despite devastating years of imprisonment, His ideas survived among his followers. He authored 33 books and pamphlets. These were published in as much as half a million copies. Thus, he must have been one of the most commonly read authors of his time. Part of his writing was translated into foreign languages and widely spread and read among puritans in the United Kingdom, Germany, France, Denmark, Sweden and Finland.

Hauge should be understood in light of international puritan waves at the time. They were in favour of individual, religious, political and economic liberalism. A core idea was that the individual was directly responsible to God. There was no clergy, royals or ceremonies, which could save, only the individual's answer to God's direct calling. The puritans were strongly overrepresented among entrepreneurs of their time. It has been claimed with significant authority that the movement in many ways played a central role in the establishment of the modern society represented by democracy, liberalism and the capitalist economy (Smith, 2010).

\section{Economic Involvement}

In 1801 Hauge earned his merchant privileges in Bergen, which at the time was the economic capital of Norway. The city, with a population of almost 17000 , was to be his base for an impressive expansion until 1804, when he was permanently arrested. He was a controversial, however, still a highly respected man under the protection of one of Norway's most admired statesmen at the turn of the century, Mr Johan Nordahl Brun (1745-1816). He was a predominant vicar in Bergen from 1774 and bishop in the city from 1804 until his death. Even after his imprisonment Hauge continued with his entrepreneurial activities and writings.

It is worth nothing that Hauge was both successful and unsuccessful in his business activities. He was often in desperate need of capital from friends and contacts. His plans for the setting up of manufacturing industry, was over ambitious, and in that respect he didn't reach his goals. At the year of his final arrest in 1804 he had to carry 
heavy losses. The value of his assets, were nevertheless higher than his debt. Due to the imprisonment he ended up indebted. However, through goodwill from his friends, business contacts and financial compensation from the government he was able to meet the requirements.

\subsection{Property}

In order to become a privileged merchant it was required to have ownership of fixed property. Hauge was able to buy a building in Bergen during the spring of 1801 for a very low price. Thus, it was possible for him to act as an independent merchant. The building was bought from his own brother in-law Johan Nicolai Loose, who became member of Hauge's network. Later, Hauge took part in consortiums buying properties in central Bergen. The buildings were taken care of by followers. In addition needy people's rents were subsidised (Breistein, pp. 120-124).

\subsection{Agriculture}

Hauge baught farms, wich were transformed to highly efficient production units. He took an active part in the purchase of Svanøe manor in Sunnfjord. He was not satisfied with the productivity during its first farm manager's rule. Thus, he gave the managing responsibilities to Ole Torjussen Helling, who proved to be a clever and innovative farmer, adding a mill, salt distillation plant and a small shipyard to the farm engagements. $\mathrm{Mr}$ Helling soon proved to be a prominent businessman in Bergen.

\subsection{Mills}

In 1815 Hauge started his own grain mill at Svartediket in Bergen. Several followed, among them Bjølsen Mill in Oslo, which became one of the biggest in Norway. At the same time he bought different farms near by Bergen and in other areas of the country. Most of them were very successful (Breistein, 1955, pp. 125-138).

\subsection{Fish Processing}

Hauge was engaged in equipping fishing boats for herring fisheries, a very dynamic industry at the time. When doing so he learned by some of his followers from the Bergen and Sunnmøre district different ways of fish preservation, like salting, drying and smoking. He saw no use in keeping this kind of information for himself, and generously shared it within his network. Clipfish, i.e. salted and dried codfish, gained market shares from dried fish, and the industry grew rapidly along the west coast of Norway. The bulk of the successful producers were puritans with relations to Hauge or his network. This connection is still evident along the coastline.

\subsection{Copper Mine}

During one of Hauge's missionary journeys in 1803 some of his followers told him they had found copper at Vingelen in Østerdalen in East-Norway. Production was soon started up with capital from some of his wealthy partners in business and faith. However, a dispute over owner rights made him go for a deal with his opponents, in which his consortium agreed to sell the mines with a considerable profit (Kvamen, 1971).

\subsection{Paper Mills}

Hauge took an active part in the establishment of a paper mill in Aadalen, Eastern Norway. Despite active opposition and accusations of document forgery from the central authorities, fearing the Haugeans to gain power over the written word, he never gave up this project. He built a paper factory in Eiker, close to the town of Drammen. His brother, Mikkel Hauge, was appointed manager. The building was completed in 1802. The plant soon had 50 employees, producing top quality paper.

On the initiative by Hauge another paper production plant was established at Fennefoss in Southern Norway. It was considered very efficient and profitable. It did function as a combined paper mill and mission hall, as became common in the rapidly growing movement (Kvamen, 1971).

\subsection{Printing House}

During his evangelical campaign in 1803 Hauge bought a printing house in Kristiansand. In this he saw a possibility of publishing his own books and even magazines and a newspaper, i.e. Christiansand Adressecontoirs Efterretninger. The business was not profitable until Mr Christoffer Andersen was appointed as manger. Christoffer and his son Martin Grøndahl made the establishment to one of the most prominent in Norway. It later moved its head office to the capital, Christiania (Breistein, 1955).

\subsection{Brick Factory}

In 1804 Hauge, due to huge crowds, had to move evangelical meetings to a former brick factory at Eeg close to Kristiansand. He soon suggested that a young man in his network, Ole Eyelsen, should restart production. The buildings were bought with Hauge as investor and banker. From 1808 it earned considerable profits and 
expanded regularly. From 1812 Eyelsen started up the production of domestic coal ovens (Breistein, 1955, pp. 137).

\subsection{Merchant Houses and Trade Stations}

From his base in Bergen Hauge bought and expanded several trade stations along the coast of South-Norway. The merchant house at the fishermen's village Sør-Giæslingan in Trøndelag is perhaps the best known of these. Hauge assisted his good friend, lay preacher, merchant and industrialist Arent Solem to buy the place. It served as a key base in a network of trade stations along the coast ensuring fairly good control of distribution of products traded by Haugians.

Hauge and his closest associates maintained their network by trade through these stations, appointing managers and providing credits. In addition he distributed business letters containing both spiritual and economic teaching. Buildings at the stations were often used as halls for evangelical meetings (Aarflot, 1979, pp. 106-114).

\subsection{Shipping}

Hauge also did career as and innovative ship-owner, however, not always with success. The idea was basically taken from his brother in-law, who traded ships with high profits. Hauge served both as shipbroker and ship-owner. The idea was to raise capital by ship broking in order to invest in ships for ownership. These could also be used in transportation of products produced or traded within his business network.

During 1803 and 1804 Hauge invested in no less than nine sailing vessels, two of these were frigates. The ships were named Forsøg (Attempt), Anna Helena, Haabet (The Hope), Nicolai, Aurora I, Aurora II, Aurora III, Stadt Bergen (City Bergen), Christiane Margaretha.

Ship broking and owning was a very risky business during the Napoleonic wars. Hauge experienced both heavy losses and impressive profits. The broking activity was additionally an important tool in order to raise fast money for investments (Breistein, 1955).

\subsection{Textile Mills}

Hauge gained increasing interest in the textile industry. The most important one established was Drammen textile mill in 1818. His followers set up several textile plants under his surveilence. In 1821 it was moved to Solbergelva at Nedre Eiker close to Drammen. It grew to become the greatest spinning mill in Norway, and a pioneer company regarding labour welfare. It continued its production until 1992. Connected to the spinning, Hauge started with textile colouring plants and production of high quality clothing (Breistein, 1955, p. 136).

\subsection{Salt Destilation}

During the war with the United Kingdom, The Danish-Norwegian King gave Hauge permission from jail in order to teach potential entrepreneurs to destil salt form seawater. Many of his students became his followers. They became a central network in fast growing fish processing industry producing salted and dried cod for exports to the European continent and later even to South-America.

\subsection{Distilleries}

Hauge was never a teetotalist, as teetotelism conquered the Norwegia puritan movement some time after his death. However, he spoke out against alcoholism and side effects of spirit consumption. However, he did not consider moderate and careful consumption as inferior conduct. In fact, he sat up several distilleries connected to farms. The aim was profits and controlled alcohol consumption.

\subsection{Investment}

In order to establish his business empire Hauge invested heavily in project ran by him self or companions. Sometimes he took active part in the projects. At other times his role was more a passive one, limiting himself to investment in pioneer or running businesses. By doing so he actively contributed to keep business going. He often invested in risky projects with borrowed money. The volume of his engagement as investor was quite impressive. His losses were surprisingly small. Through this involvement Hauge did not only contribute to his own industrial projects, but also those of his brethren in faith or just promising industrialists regardless of religious affiliation (Helgøy, 2010).

\subsection{Banking}

During almot the entire business career of Hauge there was no regular bank in Norway. He was in need of borrowed capital both for himself and others. Thus, he filled a vacancy as a banker. The capital was to a large extent based on deposits or loans from friends with available capital in savings. By doing this he became an important banker in a time when Norway lacked both commercial and saving banks. Also, Hauge tried to 
motivate some of his followers to establish saving's banks, which they to a large extent did from the mid 1820s, just after his death in 1824 .

\section{Portfolio Strategy}

As can clearly be seen, Hauge had substantial spread in his portfolio and, thus, risk distribution was taken well care of. Most of the portfolio was built up during three years, 1801-1804. During this short period of time and without any capital base the peasant's son developed to be a substantial and successful entrepreneur. He was definitely not risk averse. We find this attitude in his signet, drawn from the gospel of Mathew, chapter 13, and verses 45-46:

"Again, the kingdom of Heaven is like a merchant in search of fine pearls; on finding one pearl of great value, he went and sold all that he had and bought it."

Hauge typically appointed managers for the plants he was engaged in. Also in several projects were he took a marginal role. The appointed managers often moved quite a distance to take up their commision. It may seem, as it was a deliberate policy to recruit local leaders outside the communities. The company managers often also became spiritual leaders of the local friends. Hauge acted both as informal bishop of an informal religious body and director general of a business conglomerate. He offered both spiritual and business education to those he gave leadership responsibilities (Dalgaard, pp. 48-66). He educated his followers in technical skills, product knowledge, purchase and sales strategy, marketing, distribution, accounting, labour welfare, business strategies, theoretical and practical theology and pastoral care.

\section{Scale}

On the basis of the historical sources kept as evidence at the trial, business correspondence and financial accounts it is possible to quantify the bulk of the investments and financial engagements of Hauge 1799-1823. The numbers are impressive. We find more than 30 companies directly stemming from Hauge's entrepreneurship. Additionally, we find dozens of establishments where he contributed as investor, banker or with other resources, When adding merchant vessels, merchant activities and farms ran by members of his network, we find records of more than 150 units, where he in one way or another was involved (Breistein, 1955).

\subsection{Financial Transactions}

It is possible to follow Hauge's major financial transactions. Most of these were recorded before the arrest in October 1804. However, his financial activities also continued after the imprisonment. Hauge obviously earned considerable goodwill. For 1799-1823 we find 101 substantial transactions. In the top year 1804 alone we find 36. Additionally, we know that less important transactions were not recorded.

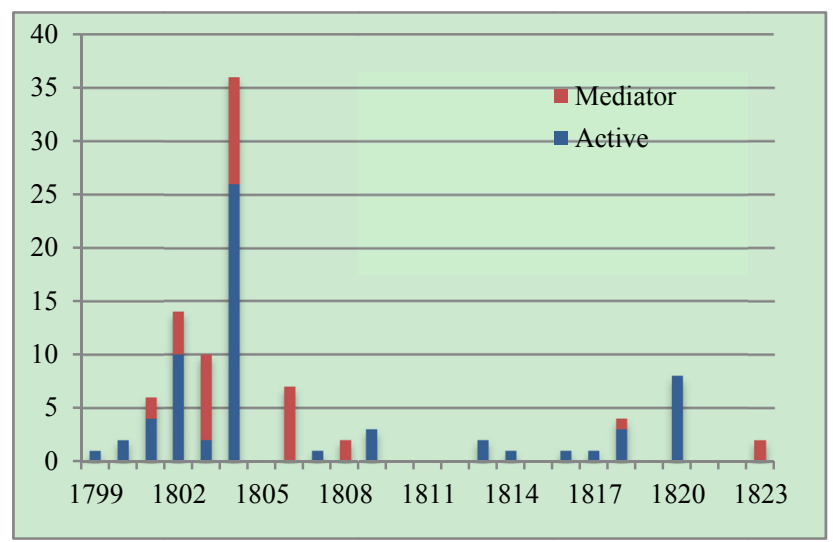

Figure 1. Number of larger financial transactions by Hauge 1799-1823

Sources: Breistein, 1955, pp. 104-206, Rødal, 2009, pp. 79-82, Kvamen, 1971-1976.

Figure 1 shows the number of larger financial transactions Hauge conducted actively (65) and as mediator (36). Due to years of imprisonment, his engagement ceased after 1804. We don't know the number of larger financial transactions in Norway at the time. But we do know that the bulk of his engagement took place before Norway had its first regular bank. The central bank was founded in 1816. The first savings bank, Christiania Sparebank, took up its engagements in 1822. The first commercial bank, Christiania Bank \& Kreditkasse, started in 1848. 


\subsection{Volume of Hauge's Financial Engagements}

We will look more closely at the volumes of the transactions. There are many problems connected to these sums. In the first place, they are reported in different kinds of currencies:

1. Speciedaler (Danish) until 1813 - par value stood at 4 kroner.

2. Rigsdaler Courant 1795-1813 - par value stood at 3.20 kroner.

3. Rigsbankdaler 1813-1818 - par value stood at 2.00 kroner.

4. Speciedaler (Norwegian) 1816-1874 - par value stood at 4.00 kroner.

Substantial inflation and money depreciation was a huge problem in the period. The three first currencies did all depreciate. We calculate them into kroner according to the par exchange rates. In order to arrive at relevant estimates of the sums, they are inflated with the general inflation rate up to present values. This is made possible by using the historical consumer price index published by the central bank (2012). The results are reported in Figure 2 .

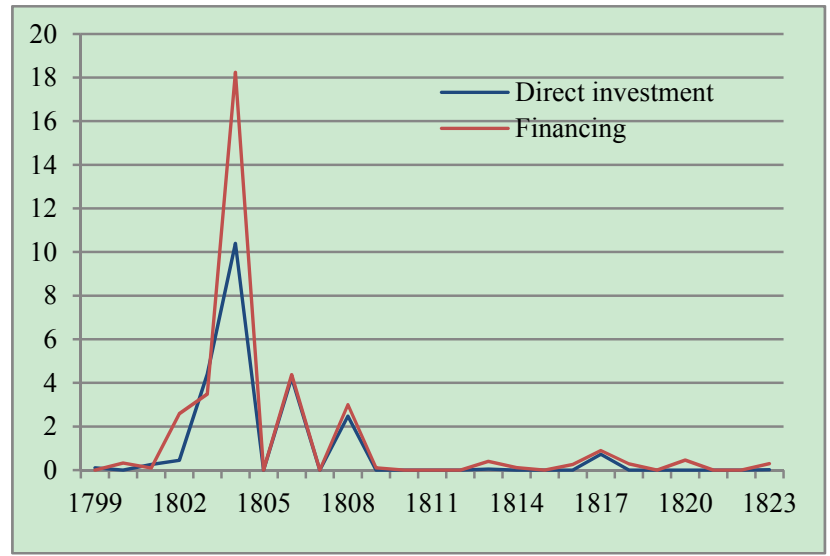

Figure 2. Significant financial transactions Hauge was involved in.

Reported in mill 2010-NOK. Inflated with the Norwegian historical CPI.

Sources: Breistein, 1955, pp. 104-206, Rødal, 2009, pp. 79-82, Kvamen, 1971-1976, Grytten,

2004a, pp. 92-93.

During the peak-year 1804 Hauge financed projects for 18.2 million 2010-kroner. At the same year he invested for 10.4 millions. We do not know the size of the total economy at the time. However, relying on one of the most prominent Norwegian economic historians ever, Hodne it is is reasonable to assume that GDP per capita stayed at a similar level to that of 1830 . This means that the Norwegian GDP in the first years of the 1800s probably hovered around 12000 million $2010 \mathrm{NOK}$. The national investment volume that year was probably about 800 million 2010 NOK (Hodne, 1998, pp. 41-61, Grytten, 2004, pp. 277-280). Given these assumptions based on the expert knowledge we have, Hauge was probably involved in between one and 1.5 percent of the Norwegian investment volume that year. At the same time he may have provided finances for sums accounting for between two and 2.5 percent of total investments. Thus, Hauge must have been a large investor and bankers at the time, despite a limited capital base.

The inflating method above has its drawbacks. One is that no price index exists for financial transactions. The most important is, however, that we do not take into account the considerable growth in purchasing power since the early 1800s. A way of accounting for this is to look at how many man-years ordinary workers had to work in order to cover the expences. Thus, the sums are calculated into wage equivalents. By using historical series of annual wages we find the number of normal man-years per transaction. In order to express these in present values we transform the number of man-years to normal wages in 2010 (Grytten 2009, pp. 48-87).

The results are shown in figure 3. According to our calculations in wage equivalents he raised 387 million for financial transactions and 220 million for investments in 1804 alone. Due to lack of records of some transactions, 
the sums were in fact even higher. Hauge's activities in the financial market fell considerably after the arrest 1804-1811 and 1813-1814. A big loser must have been the Norwegian economy.

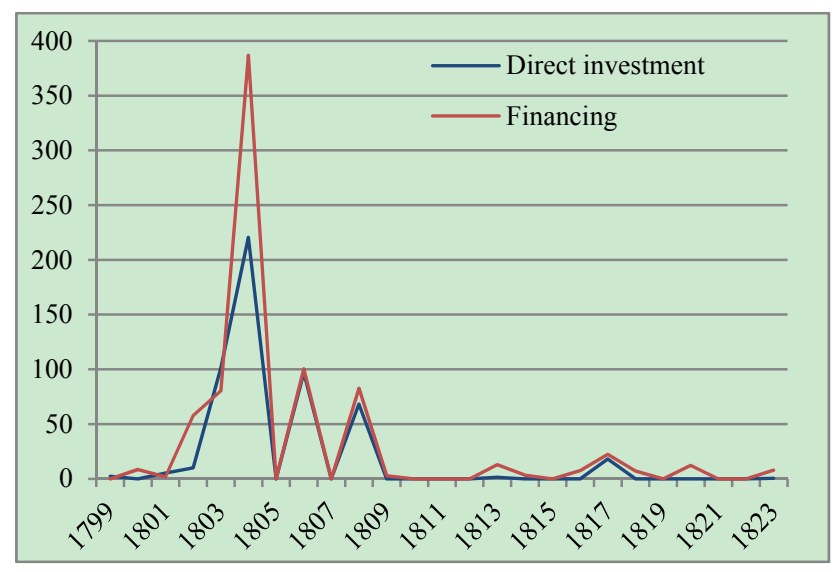

Figure 3. Significant financial transactions Hauge was involved in (Reported in wage equivalents in mill 2010-NOK)

Sources: Breistein, 1955, pp. 104-206, Rødal, 2009, pp. 79-82, Kvamen, 1971-1976, Grytten, 2009, pp. 48-87, Norges Bank, 2012, Statistics Norway, 2012.

\subsection{Investment Portfolio}

By using the available data it is possible to examine Hauge and his partners' investments more closely. In the accounts investments were either recorded as fixed capital or loans. Table 1 reports that more than 60 percent of his personal direct investments were in fixed capital in merchant or industrial activities. Close to 40 percent were granted loans to other actors. This confirms his position as a banker.

Examining transactions where Hauge played a role as a mediator, we find that they almost unanimously were invested in fixed capital. Apart from Hauge and his closest network most Haugians acted rather as entrepreneurs and investors than creditors.

Table 1. Direct investments Hauge was involved in. In mill 2010-NOK. CPI-inflated

\begin{tabular}{lccccc}
\hline & \multicolumn{2}{c}{ Mill 2010-NOK } & \multicolumn{2}{c}{ Percent } \\
Investments & Fixed capital & Loans & Total & Fixed capital & Loans \\
\hline Active & 3.079 & 2.017 & 5.096 & 60.4 & 39.6 \\
Mediator & 18.714 & 0.018 & 18.732 & 99.9 & 0.1 \\
Total & 21.793 & 2.035 & 23.828 & 91.5 & 8.5 \\
\hline
\end{tabular}

Sources: Rødal, 2009, pp. 42-43, Grytten, 2004, pp. 92-93, Norges Bank, 2012, Statistics Norway, 2012).

According to our data nine tenth of the investments Hauge was involved were spent on fixed capital. However, it is likely that loan transactions are under represented in the sample used here (Rødal, 2009, pp. 42-43).

The discrepancy between aggregated financial records and investment records amounts to 10701 million 2010-NOK. The residual was probably covering operational costs and credits. When we take this into account we end up with an investment distribution of 63.1 percent on fixed capital and 36.9 percent on loans, credits and operational costs. Thus, Hauge's banker function as mediator of capital was substantial both on the credit and the debet side.

\section{Financial Sources}

From where did Hauge and his network get their capital? Among his partners we find people with a considerable and a weak capital base. Hauge's engagement in order to assist talented entrepreneurs often made him act as a 
broker between these groups. Table 2 offers an overview of financial transactions Hauge was involved in. It reveals that the solidity was high in joint ventures, with half of the capital mobilised by loans. On projects where he was the key player, we find that 96.8 percent of the capital was granted as loans. This means a gearing coefficient of 31.2, which was very high indeed in the pre-banking Norwegian economy. Hauge must have been considered a credible debtor.

Table 2. Financial transactions Hauge was involved in. Mill 2010-NOK. CPI-inflated

\begin{tabular}{lccccc}
\hline & \multicolumn{3}{c}{ Mill 2010-NOK } & \multicolumn{3}{c}{ Percent } \\
Financing & Equity & Debt & Total & Equity & Debt \\
\hline Active & 0.578 & 17.640 & 18.218 & 3.2 & 96.8 \\
Mediator & 7.557 & 8.755 & 16.311 & 46.3 & 53.7 \\
Total & 8.134 & 26.395 & 34.529 & 23.6 & 76.4 \\
\hline
\end{tabular}

Sources: Rødal, 2009, pp. 42-43, Grytten, 2004, pp. 92-93, Norges Bank, 2012, Statistics Norway, 2012.

\section{Entrepreneurial Legacy}

As a prominent entrepreneur in difficult times for the Norwegian economy, Hauge trained many of his followers to become highly qualified merchants, industrialists and managers. They became true pioneers within business, industry, labour welfare, education, popular enlightment and formation of the Norwegian society for more than a hundred years. Many of these traditions still exist. It should be noted that neither Hauge nor his first followers created any formal organisation. The so-called Haugians were idividuals or groups, who were inspired by his work and writings in religious, ethical and behavioural ways. It is hard to tell how many they were and to which extent they were inspired by him. Brandal (1981) argues that the mentality promoted by Hauge marked entire societies along the coast, as it formed both their way of thinking and their way of conduct. Thus, the majority of entrepreneurs in these areas were influenced by his ideas.

The Norwegian writer Alexander Kielland has given descriptions of the $19^{\text {th }}$ century entrepreneurship of Haugians within the herring fisheries in one of the major cities, Stavanger. Most of these were originally peasants and fishermen who worked themselves up into the burgerois:

"Year by year they were successful: their capital increased: however, it was immediately reinvested into business. Those who one year had salted 1.000 barrels, would the next year take 3.000; they were active in all areas, set all sails, and while their conduct was silent with psalms and humble speech, they were in reality risktakers - yes, indeed audacious speculants. "(Kielland 1882).

The increase in welth was debated among the bretherens, and for some it was considered immoral conduct. Hence, some groups became negative to involvment in the business community. They often lost the dynamic momentum and retarded both in numbers and strength. However, the dynamic groups survived and took active part in the development of modern business and society (Hodne \& Grytten, 2000).

\section{Conclusions}

In order to throw light on Max Weber's hypothesis on the linkage between protestant ethics and the spirit of capitalism this paper investigates into the business activities of one of the most prominent Norwegian entrepreneurs in the eraly nineteenth century, the puritan lay preacher Hans Nielsen Hauge. Novel data sets make us able to map scale and scope of the bulk of his entrepreneurship. Despite limited initial financial strength and several set-backs, the peasant's son was chiefly, but admittedly not always, successful in his activities. During the five years 1799-1804 he established an impressive business empire as merchant, ship owner, farmer, broker, publisher, industrialist, banker and investor.

Our data suggest Hauge must have been a very important domestic banker and investor at the time. It is impossible to give precise numbers of Hauge's relative share of the Norwegian investment volume at his time. However, on the basis of estimtes offered here, one may suggest he was involved in between one and 1.5 percent of the total Norwegian investment volume in 1804. Likewise, his financial activities could have amounted to something between two and 2.5 percent of total national investments. Moreover, Hauge's nonconformist followers played a major role in creating entrepreneurial clusters in Norway for more than a hundred years after his death. 


\section{References}

Aarflot, A. (1974). Hans Nielsen Hauge, his life and message. Minneapolis, MN: Augsburg Publishing House.

Becker, S. O., \& Wossman, L. (2009). Was Weber Wrong? A Human Capital Theory of Protestant Economic History. Quarterly Journal of Economics, 124(2), 531-596. http://dx.doi.org/10.1162/gjec.2009.124.2.531

Brandal, T. (1981). Frå fjørestein til fjerne farvatn: Fiske og fangst i Hareid og Ulstein ca 1880-1920. Bergen, Norway: University of Bergen.

Breistein, D. (1955). Hans Nielsen Hauge, Kjøbmand i Bergen. Bergen, Norway: John Griegs forlag.

Bull, J. B. (1908). Hans Nielsen Hauge. Oslo, Norway.

Cantoni, D. (2009). The Economic Effects of the Protestant Reformation: Testing the Weber Hypothesis in the German Lands. Job Market Paper. Boston, MA: Harvard University. Retrieved from http://www.people.fas.harvard.edu/ cantoni/cantoni_jmp_2_7_1.pdf

Christoffersen, S. A. (Ed.) (1996). Hans Nielsen Hauge og det moderne Norge. Oslo, Norway: KULT/NAV.

Dalgaard, B. R., \& Supphellen, M. (2011). Entrepreneurship in Norway's economic and religious nineteenth-century transformation. Scandinavian Economic History Review, 59(1), $48-66$. http://dx.doi.org/10.1080/03585522.2011.541123

Eitrheim, Ø. (2005). Fra Bogstad Gård til pengestabilitet. In Ø. Eitrheim, \& J. Qvigstad (Eds.), Tilbakeblikk på norsk pengehistorie (pp. 1-18). Oslo, Norway: Norges Bank.

Elseth, E. (1998). Hans Nielsen Hauge: Bondegutten som satte Norge på ende. Oslo, Norway: Gyldendal Tiden.

Engerman, S. (2000). Review of Max Weber: The Protestant Ethic and the Spirit of Capitalism Economic. Review article, EH.NET. Rertrieved from http://eh.net/bookreviews/library/engerman

Furre, B. (1997). Hans Nielsen Hauge - kva slags opprør?' In O. Grepstad (Ed.), B. Furre: Sant og visst. Artiklar, foredrag og preiker. Oslo, Norway: Samlaget.

Grier, R. (1997), The Effect of Religion on Economic Development: A Cross National Study of 63 Former Colonies. Kyklos, 50(1), 47-62. http://dx.doi.org/10.1111/1467-6435.0003

Grossman, H. (1934). The Beginnings of Capitalism and the New Mass Morality. Journal of Classical Sociology, $6(2), 201-213$.

Grytten, O. H. (2004a). A consumer price index for Norway 1516-2003. In Ø. Eitrheim, J. T. Klovland, \& J. F. Qvigstad (Eds.), Historical Monetary Statistics for Norway 1819-2003 (pp. 47-98). Oslo, Norway: Norges Bank.

Grytten, O. H. (2004b). The gross domestic product for Norway 1830-2003. In In Ø. Eitrheim, J. T. Klovland, \& J. F. Qvigstad (Eds.), Historical Monetary Statistics for Norway 1819-2003 (pp. 241-288). Oslo, Norway: Norges Bank.

Grytten, O. H. (2007). Norwegian wages 1726-2006 classified by industry. In Ø. Eitrheim, J. T. Klovland \& J. F. Qvigstad (Eds.), Historical Monetary Statistics for Norway - part II. Oslo, Norway: Norges Bank, 343-383.

Grytten, O. H. (2009). Purchasing Power of Labour: Norwegian Real Wages, 1726-2006. Scandinavian Economiv History Review, 57(1), 48-87. http://dx.doi.org/10.1080/03585520802700256

Hattersley, R. (1999). Blood and Fire: William and Catherine Booth and The Salvation Army. London, England: Little Brown.

Hauge, A. (1947). Hans Nielsen Hauge: Guds vandringsmann. Oslo, Norway: Ansgar.

Hauge, H. N. (1796). Betraktninger over Verdens Daarlighed. Christiania, Norway: Hauge.

Hauge, H. N. (1800). Christendommens Laerdoms Grunde. København, Denmark: Hauge.

Hauge, H. N. (1802, October). Bergens Adressecontoirs Efterretninger. Bergen, Norway.

Hauge, H. N. (1804). Forklaring over Loven og Evangelium. Bergen, Norway: Hauge.

Helgøy, E. N. (2010). Den haugianske etikk og kapitalismens ånd: En studie av haugianismens etikk for moderne virksomheter. Bergen, Norway: NHH.

Hodne, F., \& Grytten, O. H. (2002). Norsk økonomi i det 20 århundre. Bergen, Norway: Fagbokforlaget.

Hodne, F., \& Grytten, O. H. (2000). Norsk økonomi i det 19 århundre. Bergen, Norway: Fagbokforlaget. 
Hodne, F. (1981). Norsk økonomisk historie 1815-1970. Oslo, Norway: Cappelen.

Hodne, F. (1998). Verdiskapingen i manufaktur og industri i Norge 1817-1829. In O. H. Grytten. (Ed.), Nordic Historical National Accounts. Bergen, Norway: Fagbokforlaget.

Hofstad, E. (1940). Illustrert norsk nceringsleksikon: Hva er hva i nceringslivet: Vest- og Nord-Norge (Vol. 3) Oslo, Norway.

Hovland, E. (1978). Åkerbruket i Norge i begynnelsen av 1800-tallet. Historisk tidsskrift, 57(4), 331-346.

Iannaconne, L. R. (1998). Introduction to the Economics of Religion. Journal of Economic Literature, 36(3), 1465-1496.

Jeremy, D. J. (Ed.). (1998). Religion, Business and Wealth in Modern Britain. London, England: Routledge.

Jonassen, C. (1947). The Protestant Ethic and the Spirit of Capitalism in Norway. American Sociological Review, 12(12).

Kielland, A. (1882). Skipper Worse. Oslo, Norway: Gyldendal norsk Forlag.

Klovland, J. T. (2004). Historical exchange rate data 1819-2003'. In Ø. Eitrheim, J. T. Klovland, \& J. F Qvigstad (Eds.), Historical Monetary Statistics for Norway 1819-2003. Oslo, Norway: Norges Bank, 289-327.

Koht, H. (1934). Årsakene til at regjeringa grep inn mot Hans Nielse Hauge. Historisk tidsskrift, 30, 53-57.

Korotayev, A. (2006), Reconsidering Weber: Literacy and the Spirit of Capitalism. In A. Korotayev (Eds.), Introduction to Social Macrodynamics (pp. 87-91). Moscow, Russia: Rossiřskir gosudarstvennyı̄ gumanitarnyı̆ universitet.

Kristiansen, O. (1925). Penge, kapital og nceringsveie: Bidrag til Norges økonomiske historie1815-1830. Oslo, Norway: Cammermeyers Boghandels Forlag.

Kullerud, D. (1996). Hans Nielsen Hauge: Mannen som vekket Norge. Oslo, Norway: Forum Aschehoug.

Kvamen, I. (1971-1976). Brev frå Hans Nielsen Hauge (Vol. 4). Oslo, Norway: Lutherstiftelsen.

Lindstøl, T. (1914), Stortinget og Statsraadet 1814-1914, Kristiania.

Lunden, K. (1980). Norsk økonomi under dansk styre. Historisk tidsskrift, 59(4), 88-108.

Magnus, A. J. (1978). Revival and Society: An Examination of the Haugian Revival and Influence on the Norwegian Society in the $19^{\text {th }}$ Century. Oslo, Norway: UiO.

Magnus, A. J. (1996). Veirydder med gnagsair: Hans Nielsen Hauge og vekkelsen som forandret Norge. Grimerud, Norway: Prokla Media.

McCleary, R. M., \& Barro, R. J. (2006). Religion and Economy. Journal of Economic Perspectives, 20(2), 49-72. Retrieved from http://dx.doi.org/10.1257/jep.20.2.49

McCullough, M. E., \& Willoughby, B. L. B. (2009). Religion, Self-Regulation, Self-Control: Associations, Explanations, and Implications. Psychological Bulletin, 135(1), 65-91. http://dx.doi.org/10.1037/a0014213

Norborg, S. (1966). Hans Nielsen Hauge: Biografi 1804-1824 Oslo, Norway: Cappelen.

Norges Bank. (2012). Consumer price indices. Retrieved from $\mathrm{http}: / /$ www.norges-bank.no/templates/article_42931.aspx

Ravnåsen, S. (2002). And og hånd, Hans Nielsen Hauges etikk for ledelse og nceringsliv. Oslo, Norway: Luther forlag.

Robertson, H. M. (1933). Aspects of the Rise of Economic Individualism: A Criticism of Max Weber and His School. Cambridge, MA: Cambridge Univesity Press.

Rødal, V. T., \& Kiplesund, A. (2009). Hans Nielsen Hauge: Entrepreneur, Banker and Industrialist. Bergen, Norway: NHH. Retrieved from http://brage.bibsys.no/nhh/bitstream/URN:NBN:no-bibsys_brage_24216/1/Rodal\%202009.pdf

Schumpeter, J. (1939). Business Cycles: A theoretical, historical and statistical analysis of the Capitalist process. New York, NY: McGraw-Hill.

Sejersted, F. (1993). Demokratisk kapitalisme. Oslo, Norway: Universitetsforlaget.

Shaw, J. M. (1955). Pulpit Under the Sky: a Life of Hans Nielsen Hauge. Minneapolis, MN: Augsburg Publishing House. 
Sjursen, F. W. (1997). Artikler om Hans Nielsen Hauge, haugianismen og bevegelsens betydning for kultur og opplysningsarbeid. Bergen, Norway: NLA-forlaget.

Smith, R. (2010). Puritanism in Early American History. Retrieved from http://www.helium.com/items/488403-puritanism-in-early-american-history

Statistics Norway. (2012). Consumer Price Index. Retrieved from http://www.ssb.no/emner/08/02/10/kpi/tab-2010-02-10-01.html

Supphellen, S. (2012). Konventikkelplakatens historie 1741-1842. Trondheim Studies in History. Trondheim, Norway: Tapir Akademisk Forlag.

Tawney, R. H. (1926). Religion and the Rise of Capitalism. Gloucester, MA: Peter Smith (reprint 1962).

Vea, J. (2009). To kulturer. Kristiansand, Norway: Høyskoleforlaget.

Weber, M. (1905). Die protestantische Ethik und der Geist des Kapitalismus. Berlin.

Weber, M. (1930). The Protestant Ethic and the Spirit of Capitalism. New York, NY: Charles Scribner's Sons (reprint 1958).

Young, C. (2009). Religion and Economic Growth in Western Europe: 1500-2000. Manuscript. Stanford: Stanford University.

Retrieved

from http://www.stanford.edu/ cy10/public/Religion_and_Economic\%20Growth_Western_Europe.pdf 